\title{
Celiac Disease and Imbalance of Intestinal Flora
}

\author{
Taufner $\mathrm{GH}^{1 *}$, Barcelos $\mathrm{DHF}^{3}$, Barcelos $\mathrm{IF}^{1}$ and Destefani $\mathrm{AC}^{3}$ \\ 1Biomedic, Federal University of Espírito Santo (UFES), Brazil \\ 3Biologist, Federal University of Espírito Santo (UFES), Brazil \\ 4Pharmacist Biochemist, Federal University of Espírito Santo (UFES), Brazil
}

Submission: January 25, 2017; Published: February 27, 2017

*Corresponding author: Taufner GH, Biomedic, Master student in Biotechnology from the Federal University of Espírito Santo (UFES), Av. Marechal Campos, 1468 - Maruípe, Vitória/ES - Brazil, CEP 29043-900, Brasil, Email: Gabrielhtaufner@hotmail.com

\begin{abstract}
Celiac disease is an autoimmune pathology of a genetic nature triggered by the consumption of gluten and characterized by histological changes in the intestine of genetically arranged patients. The characteristic symptoms of CD are diarrhea, constipation, pain and abdominal distension. Allied to this symptomatic set is the imbalance of the human intestinal tract (GI) microbiome, a complex that has in its composition a range of microorganisms that contributes immensely to the metabolism physiology and to maintain the health of the host.Changes in this system leads to a condition known as dysbiosis, where the intestinal microbiota becomes unbalanced and can trigger numerous gastrointestinal complications, including celiac disease.
\end{abstract}

Keywords: Celiac disease; Microbiome; Intestinal flora

\section{Introduction}

Celiac disease (CD) is an autoimmune disease that affects individuals who are consumers of gluten and who are genetically predisposed [1-4]. It is characterized by histological changes in the small intestine, such as atrophy of the intestinal villi and stretching of the crypts, which consequently leads to a reduction in the area of nutrient absorption [5,6]. The CD can be manifested in a classic, non-classic or asymptomatic way, with or without signs and symptoms, which can often be correlated with associated complications [6-11]. The characteristic symptoms of celiac disease are diarrhea, constipation, pain, and abdominal distension [12-14]. In addition to the characteristic intestinal complications, there is the consequent imbalance of the human intestinal tract (GI) microbiome. This biome is complex in its composition and contributes immensely to the physiology of nutrient absorption and maintenance of host health [15]. Changes in this system leads to a condition known as dysbiosis, where the intestinal microbiota becomes unbalanced and can trigger numerous gastrointestinal complications, including celiac disease $[16,17]$. It is believed that the normal intestinal microbiota is composed of microorganisms of 5-7 of the 52 bacterial phyla currently recognized [18]. Considering the important role of these microorganisms, this article aims to carry out a bibliographic review on the importance of the symbiotic relationship of the microbiota with man.

\section{Literature Review}

\section{Celiac disease}

The Celiac disease is a permanent intolerance to gluten, characterized by total or subtotal atrophy of the proximal small intestinal mucosa and stretching of the intestinal crypts, resulting in malabsorption of food in genetically susceptible individuals $[7,10,19]$. It begins as an inflammation in the duodenum (duodenitis, infiltration of cells of the immune system, such as $\mathrm{T}$ lymphocytes). The celiac patient has an abnormal immune response to peptides derived from gliadin and glutenin. Sensitive CD4+ T lymphocytes recognize multiple gluten epitopes through presentation through the molecules DQ2 and DQ8. Activated lymphocyte clones proliferate and produce various proinflammatory cytokines responsible for the stimulation of cytotoxic $\mathrm{T}$ cells by promoting cell infiltrate and producing metalloproteinases that damage the extracellular matrix $[3,6,20-22]$.

\section{Complications}

The only treatment available for CD is the total exclusion of gluten from the diet $[19,23,24]$. Failure to implement the treatment may lead celiac patients to present, in addition to the classic symptoms, several types of malignant and non-malignant complications that encompass several other 
organs and systems and which often do not show significant gastrointestinal symptoms. We highlight as non-malignant complications osteoporosis, infertility, obstetric complications, pulmonary hemosiderosis, neurological and psychiatric disorders, intestinal bleeding and intestinal ulcers, as well as an infinity not yet studied [25-29]. As malignant complications, of a more serious character, we can highlight lymphoma in the small intestine, carcinoma of the esophagus and pharynx, as well as adenocarcinoma of the small intestine whose etiopathogenesis is little elucidated $[10,13,30]$. In addition to these complications, $\mathrm{CD}$ is being correlated with several autoimmune diseases, including type I diabetes, Down syndrome and Turner syndrome [11,31-33]. In case of persistent inadequate diet, symptoms of gluten intolerance persist and lead to disorders that also affect the intestinal flora, which consists of an important set of microorganisms that co-exist with humans and participate in important metabolic functions, in addition to exert an indispensable function of defending the organism against pathogens by preventing external microorganisms or even the microbiota itself from causing infections [34,35]. Severe disorders in this system can trigger various intestinal or extraintestinal disorders such as intestinal we can highlight the worsening and / or installation of celiac disease, inflammatory bowel disease and irritable bowel syndrome, while extraintestinal include allergy, asthma, metabolic syndrome, diseases cardiovascular and obesity $[15,17,18]$.

\section{Intestinal flora}

The human body is colonized by microorganisms on all surfaces that are topologically attached to the external environment, such as skin, respiratory tract, gastrointestinal tract and genitals.In recent years, there has been an explosion of interest in understanding the structure, function and ecology of the human microbiota to understand the mechanisms of various pathologies [16].

The gastrointestinal tract (GI) is colonized by a dense community of commensal microorganisms referred to as the intestinal flora. It is believed to be composed of a population of $10^{14}$ bacterias distributed in 160 different species, in addition to viruses, fungi and archaea [36]. The presence and composition of the microbiome is mainly determined by physical factors such as the availability of nutrient sources, temperature or the presence of $\mathrm{O}^{2}$, in addition to interactions between microorganisms through antibiotic toxins and intercellular communication. It is therefore not surprising that microbial communities vary dramatically along the length of the gastrointestinal tract and that mucosal adherent microbial communities differ significantly in lumen and faeces $[37,38]$.

The intestinal microbiota co-evolved with man and plays an important role in physiological processes related to immunity and metabolism acting positively to maintain host health $[36,39,40]$. In immunogenic processes, we highlight its role in protecting intestinal lumen epithelium by competing with microorganisms that may cause opportunistic infections, production and secretion of bacteriocins, stimulation of antimicrobial peptide production by epithelial cells, IgA synthesis and the promotion of good functioning of the cellular junctions, which reduces the possible invasion of the tissue by pathogenic bacteria $[36,41]$. In metabolism, the microorganisms of the intestinal microbiota participate in the biotransformation of nutrients such as lipids, carbohydrates and unabsorbed proteins in the upper digestive tract, causing a certain ease in the absorption of the intestinal villi $[42,43]$. In addition, they benefit from having the same bioavailable nutrients for the host as energy source.

The occurrence of some imbalance in the microorganisms of the microbiome may lead to a state known as dysbiosis, where the altered intestinal microbiota may cause the development of various gastrointestinal diseases including inflammatory bowel disease, colon cancer, celiac disease, and irritable bowel syndrome, As well as extra intestinal diseases such as obesity and autism $[36,39,44]$. There is a growing body of evidence to suggest that multiple intrinsic and extrinsic factors such as genetic variation, diet, stress, and medication can dramatically affect the balance of the intestinal microbiota $[16,17]$.

\section{Influence of intestinal flora in DC}

Recently, many studies have addressed the importance of intestinal flora in the development / evolution of celiac disease, showing the relationship between the change in the structure of intestinal cells, such as increased permeability and its detachment, influences the aggravation and development of the main symptoms of celiac disease $[45,46]$. In the equilibrium of the intestinal microenvironment, each bacterium presents its function, but when a disturbance occurs in this environment, mainly through the reduction of certain bacterial groups considered probiotic, other bacteria can multiply and gain access to the cells of the endothelium of free form, this ends for causing a number of problems $[47,48]$. In the composition of the intestinal flora of healthy people it is common to find bacteria belonging to the genus Lactobacilluss spp. And Bifidobacterium spp. [49]. These bacteria are responsible for the degradation of gluten polypeptides, protecting the cells of the intestinal epithelium, which leads to less irritation and inflammation of the intestine, as well as compete in the environment against pathogenic bacteria, thus preventing them from freely propagating through the intestine of the host $[50,51]$. Studies have shown that the intestinal microbiota of individuals with celiac disease, when compared to healthy individuals, present a lower number of Lactobacillus spp. and Bifidobacterium spp., and an increase in the number of bacteria that can cause intestinal diseases $[15,52,53]$.

The bacteria that make up the genus Lactobacillus spp. are Gram-positive, microarefilas and have as final product of the metabolism carbon and lactate [54]. The Lactobacillus may present a new guideline in the treatment of DC, thanks to its enzymes that have the ability to degrade gluten. Biotechnology 
tests have selected species of this genus, which are efficient and low in toxicity, for use in breads and pasta, and in some cases even in wheat flour composition, causing the gluten proteins to arrive degraded in the intestine of the consumer, which reduces the incidence of inflammation of intestinal epithelial cells [5557].

The genus Bifidobacterium spp. Deserves special attention among probiotics that help maintain and function the intestinal flora. This genus is formed by Gram-positive and anaerobic batteries, which have the capacity to produce antibacterial compounds such as organic acids and bacteriocins [58]. From the metabolic point of view, they are able to produce lactic acid and acetic acid without the production of $\mathrm{CO}_{2}$, which leads to reduced production of intestinal gases [59]. The Bifidobacterium species, which colonize humans, have the ability to utilize glucose, galactose, lactose and fructose as carbon sources. Thanks to these characteristics of their metabolism, they are great inhibitors of pathogenic bacteria, both Gram-positive and negative [47]. Analyzing the context of the importance of these two bacterial genera, in maintaining the normal functions of the intestine, it is possible to infer that an increase in their quantity would probably lead to a control of the celiac disease, mainly the inflammation of the intestinal epithelium, and a consequent improvement in the patients' lives [60].

The presence of Gram-negative bacteria, such as enterobacterias, is normal, being commonly located in the intestinal tract of humans, and although they are mainly pathogenic, do not cause problems in their host, but when they are in a larger number can cause problems [61]. Among the major bacteria in this group are Escherichia coli, Salmonella sp., Shigella sp., which are known to cause health problems due to their toxins. Their excessive presence in the intestines of people with celiac disease can lead to an even greater decrease in gluten tolerance due to the fact that this group of cells produce toxins and lodge in enterocytes, causing more irritation to the cells and reducing the amount of bacteria which aid in the degradation of gluten $[62,63]$. Another bacterial genus that stands out, in relation to the increase of its quantity present in the intestinal flora of coeliacs, is Clostridium spp. Bacteria of this genus are known to produce toxins that cause a range of problems in humans [64]. The main bacterium in this group colonizing the intestine is Clostridium difficile, responsible for the production of two toxins of high pathological effect, known as Toxin A and Toxin B $[65,66]$. Both are enterotoxins, which exhibit a high degree of cytotoxicity, and have the ability to affect intestinal epithelial cells, disrupting their functioning and causing tissue damage [67]. An intact intestinal epithelium prevents the action of pathogenic bacteria normally found in the intestinal flora of humans Human beings, so the action of these toxins leads to a worse perspective in the evolution of the disease $[2,68]$.

Understanding how microbial flora is composed and what type of influence the major bacteria exert on the human body can be an important factor in improving the quality and efficacy of treatments in patients suffering from some intestinal disease, such as celiac disease, As well as improving the quality of life of these individuals $[69,70]$.

\section{References}

1. Araújo HMC, Araújo WMC, Botelho RBA, Zandonadi RP (2010) Celiac disease, eating habits and practices, and quality of life. Rev Nutr 23(3): 467- 474

2. Sollid LM, Jabri B (2013) Triggers and drivers of autoimmunity: lessons from coeliac disease. Nat Rev Immunol 13(4): 294-302.

3. Kupfer SS, Jabri B (2012) Pathophysiology of celiac disease. Gastrointest Endosc Clin N Am 22(4): 639-660.

4. Dicke WK, Weijers HA, Van De Kamer JH (1953) Coeliac disease. II. The presence in wheat of a factor having a deleterious effect in cases of coeliac disease. Acta Paediatr 42(1): 34-42.

5. Casellas F, Rodrigo L, Vivancos JL, Riestra S, Pantiga C, et al. (2008) Factors that impact health-related quality of life in adults with celiac disease: a multicenter study. World J Gastroenterol 14(1): 46-52.

6. Nobre S R, Silva T, Cabral JEP (2007) Doença celíaca revisitada. J Port Gastroenterol 14: 184-193.

7. Sdepanian VL, Morais M B de, Fagundesneto U (1999) Doença celíaca: a evolução dos conhecimentos desde sua centenária descrição original até os dias atuais. Arq Gastroenterol 36(4): 244-257.

8. Sdepanian VL, Morais MB de, Fagundes Neto U (2001) Doença celíaca: características clínicas e métodos utilizados no diagnóstico de pacientes cadastrados na Associação dos Celíacos do Brasil. J Pediatr (Rio. J) 77: 131-138.

9. Shannahan S, Leffler DA (2017) Diagnosis and Updates in Celiac Disease. Gastrointest Endosc Clin N Am 27(1): 79-92.

10. Freeman HJ (2009) Adult celiac disease and its malignant complications. Gut Liver 3(4): 237-246.

11. Kumar V, Rajadhyaksha M, Wortsman J (2001) Celiac disease associated autoimmune endocrinopathies. Clin Diagn Lab Immunol 8(4): 678-685.

12. Green P H, Rostami K, Marsh DM M N (2005) Diagnosis of coeliac disease. Best Pract Res Clin Gastroenterol 19: 389-400.

13. Brousse N, Meijer JWR (2005) Malignant complications of coeliac disease. Best Pract Res Clin Gastroenterol 19(3): 401-412.

14. Oliveira RP (2007) High prevalence of celiac disease in Brazilian blood donor volunteers based on screening by IgA antitissue transglutaminase antibody. Eur J Gastroenterol Hepatol 19(1): 43-49.

15. Carding S, Verbeke K, Vipond DT, Corfe BM, Owen LJ (2015) Dysbiosis of the gut microbiota in disease. Microb Ecol Heal Dis 26.

16. Pace LA, Crowe SE (2016) Complex Relationships Between Food, Diet, and the Microbiome. Gastroenterol. Clin North Am 45(2): 253-265.

17. Nagao Kitamoto H, Kitamoto S, Kuffa P, Kamada N (2016) Pathogenic role of the gut microbiota in gastrointestinal diseases. Intest Res 14(2): 127-138.

18. Sanz Y (2015) Microbiome and Gluten. Ann Nutr Metab 67(2): 28-41.

19. Moscoso JF, Quera PR (2016) Enfermedad celíaca revisión. Rev Med Chil 144: 211-221.

20. Lepers S, Couignoux S, Colombel JF, Dubucquoi S (2004) Celiac disease in adults: new aspects. La Rev Med interne 25(1): 22-34.

21. Barker JM, Liu E (2008) Celiac disease: pathophysiology, clinical manifestations, and associated autoimmune conditions. Adv Pediatr 55: 349-365. 
22. Koning F (2014) Pathophysiology of Celiac Disease. J Pediatr Gastroenterol Nutr 59: 1-4.

23. Green P H R, Cellier C (2007) Celiac Disease. N Engl J Med 357: 1731 1743.

24. Ciacci C (2015) The gluten-free diet and its current application in coeliac disease and dermatitis herpetiformis. United Eur Gastroenterol 3: $121-135$.

25. Martins CL da S (2006) Doença celíaca e infertilidade feminina: associação freqüentemente negligenciada. Rev Bras Ginecole Obs 28(10): 601-606.

26. Kumar A (2011) Latent celiac disease in reproductive performance of women. Fertil Steril 95(3): 922-927.

27. Fitzpatrick LA (2002) Secondary Causes of Osteoporosis. Mayo Clin Proc 77(5): 453-468.

28. Nacaroglu HT (2015) Association of celiac disease with idiopathic pulmonary hemosiderosis; Lane Hamilton syndrome. Iran J Pediatr 25(5): 63-65.

29. Moleski SM (2015) Increased rates of pregnancy complications in women with celiac disease. Ann Gastroenterol 28: 236-240.

30. Catassi C, Bearzi I, Holmes GKT (2005) Association of celiac disease and intestinal lymphomas and other cancers. Gastroenterology 128(4): 79-86.

31. Melo FM De (2005) Associação Entre Marcadores Sorológicos de Doença Celíaca e das Doenças Autoimunes da Tireóide Francisco. Arq Bras Endocrinol Metab 49: 542-547.

32. Lauret, E, Rodrigo L (2013) Celiac disease and autoimmune-associated conditions. Biomed Res Int.

33. Mårild K, Størdal K, Hagman A, Ludvigsson J F (2016) Turner Syndrome and Celiac Disease: A Case-Control Study. Pediatrics 137(2).

34. Sirisinha S (2016) The potential impact of gut microbiota on your health: Current status and future challenges. Asian Pacific J allergy Immunol 34(4): 249-264.

35. Shreiner A B, Kao JY, Young VB (2015) The gut microbiome in health and in disease. Curr Opin Gastroenterol 31(1): 69-75.

36. Landman C, Quévrain E (2016) Gut microbiota: Description, role and pathophysiologic implications. La Rev Med Interne 37(6): 418-423.

37. Yasuda K (2015) Biogeography of the Intestinal Mucosal and Lumenal Microbiome in the Rhesus Macaque. Cell Host \& Microbe 17(3): 385391

38. Stearns JC (2011) Bacterial biogeography of the human digestive tract. Sci Rep 1: 170.

39. Cenit MC, Codoñer Franch P, Sanz Y (2016) Gut Microbiota and Risk of Developing Celiac Disease. J Clin Gastroenterol 50: 148-152.

40. Gerritsen J, Smidt H, Rijkers GT, de Vos WM (2011) Intestinal microbiota in human health and disease: the impact of probiotics. Genes Nutr 6(3): 209-240.

41. Hooper LV (2004) Bacterial contributions to mammalian gut development. Trends Microbiol 12(3): 129-134.

42. Pryde SE, Duncan SH, Hold GL, Stewart CS, Flint HJ (2002) The microbiology of butyrate formation in the human colon. FEMS Microbiol Lett 217(2): 133-139.

43. Christl S U, Murgatroyd P R, Gibson G R, Cummings J H (1992) Production, metabolism, and excretion of hydrogen in the large intestine. Gastroenterology 102(4): 1269-1277.

44. Festi D (2014) Gut microbiota and metabolic syndrome. World J Gastroenterol 20(43): 16079-16094.
45. Richards JL, Yap YA, McLeod KH, Mackay CR, Mariño E (2016) Dietary metabolites and the gut microbiota: an alternative approach to control inflammatory and autoimmune diseases. Clin Transl Immunol 5: 82.

46. Olivares M (2015) The HLA-DQ2 genotype selects for early intestinal microbiota composition in infants at high risk of developing coeliac disease. Gut 64: 406-417.

47. Harnett J, Myers S P, Rolfe M (2016) Probiotics and the Microbiome in Celiac Disease: A Randomised Controlled Trial. Evidence-Based Complement. Altern Med 1-16.

48. Wacklin P (2014) Altered Duodenal Microbiota Composition in Celiac Disease Patients Suffering From Persistent Symptoms on a Long-Term Gluten-Free Diet. Am J Gastroenterol 109: 1933-1941.

49. Turroni F (2014) Molecular dialogue between the human gut microbiota and the host: a Lactobacillus and Bifidobacterium perspective. Cell Mol Life Sci 71(2): 183-203.

50. Di Gioia D, Aloisio I, Mazzola G, Biavati B (2014) Bifidobacteria: their impact on gut microbiota composition and their applications as probiotics in infants. Appl Microbiol Biotechnol 98(2): 563-577.

51. Arboleya S, Watkins C, Stanton C, Ross RP (2016) Gut bifidobacteria populations in human health and aging. Front Microbiol 7: 1-9.

52. Klemenak M, Dolinšek J, Langerholc T, Di Gioia D, Mičetić Turk D (2015) Administration of Bifidobacterium breve Decreases the Production of TNF- $\alpha$ in Children with Celiac Disease. Dig Dis Sci 60(11): 3386-3392.

53. Shahbazkhani B (2015) Non-Celiac Gluten Sensitivity Has Narrowed the Spectrum of Irritable Bowel Syndrome: A Double-Blind Randomized Placebo-Controlled Trial. Nutrients 7(6): 4542-4554.

54. Hammes W P, Hertel C (2006) The Prokaryotes. 320-403.

55. Di Cagno R (2005) Pasta Made from Durum Wheat Semolina Fermented with Selected Lactobacilli as a Tool for a Potential Decrease of the Gluten Intolerance. J Agric Food Chem 53(11): 4393-4402.

56. Sollid LM, Khosla C (2005) Future therapeutic options for celiac disease. Nat Clin Pract Gastroenterol Hepatol 2(3): 140-147.

57. Halmos EP (2016) Consistent Prebiotic Effect on Gut Microbiota With Altered FODMAP Intake in Patients with Crohn's Disease: A Randomised, Controlled Cross-Over Trial of Well-Defined Diets. Clin Transl Gastroenterol 7: 164.

58. Laparra JM, Olivares M, Sanz Y (2013) Role of Gut Microbes in Celiac Disease Risk and Pathogenesis. Celiac Disease 81-94.

59. Thomas LV, Ockhuizen T, Suzuki K (2014) Exploring the influence of the gut microbiota and probiotics on health: a symposium report. $\mathrm{Br} \mathrm{J}$ Nutr 112(1): 1-18.

60. Losurdo G, Principi M, Iannone A, Ierardi E, Di Leo A (2016) The Interaction Between Celiac Disease and Intestinal Microbiota. J Clin Gastroenterol 50(2): 145-147.

61. Marasco G (2016) Gut Microbiota and Celiac Disease. Dig Dis Sci 61(6): $1461-1472$

62. de Sousa Moraes LF, Grzeskowiak LM, de Sales Teixeira TF, Gouveia Peluzio M do C (2014) Intestinal microbiota and probiotics in celiac disease. Clin Microbiol Rev 27(3): 482-489.

63. Collado M C, Calabuig M, Sanz Y (2007) Differences between the fecal microbiota of coeliac infants and healthy controls. Curr Issues Intest Microbiol 8(1): 9-14.

64. Sánchez E (2011) Influence of environmental and genetic factors linked to celiac disease risk on infant gut colonization by Bacteroides species. Appl Environ Microbiol 77(15): 5316-5323.

65. Voth DE, Ballard JD (2005) Clostridium difficile Toxins: Mechanism of Action and Role in Disease. Clin Microbiol Rev 18: 247-263. 
66. Vijay Shankar, Matthew J Hamilton, Alexander Khoruts, Amanda Kilburn, Tatsuya Unno, et al. Species and genus level resolution analysis of gut microbiota in Clostridium difficile patients following fecal microbiota transplantation. Microbiome, DOI: 10.1186/2049-2618-2-13.

67. Chumbler NM1, Rutherford SA, Zhang Z, Farrow MA, Lisher JP, et al. (2016) Crystal structure of Clostridium difficile toxin A. Nat Microbiol pii: 15002.

68. Nylund L, Kaukinen K, Lindfors K (2016) The microbiota as a component of the celiac disease and non-celiac gluten sensitivity. Clin Nutr Exp 6:17-24.
69. Caporaso JG, Lauber CL, Costello EK, Berg-Lyons D, Gonzalez A, et al. (2011) Moving pictures of the human microbiome. Genome Biol 12(5): R50.

70. Hajela N, Ramakrishna BS, Nair GB, Abraham P, Gopalan S, et al. (2015) Gut microbiome, gut function, and probiotics: Implications for health. Indian J. Gastroenterol 34(2): 93-107.

\begin{tabular}{l} 
Your next submission with Juniper Publishers \\
will reach you the below assets \\
- Quality Editorial service \\
- Swift Peer Review \\
- Reprints availability \\
- E-prints Service \\
- Manuscript Podcast for convenient understanding \\
- Global attainment for your research \\
- Manuscript accessibility in different formats \\
( Pdf, E-pub, Full Text, Audio) \\
- Unceasing customer service \\
Track the below URL for one-step submission \\
https://juniperpublishers.com/online-submission.php \\
\hline
\end{tabular}

